\title{
Seasonal water level fluctuations: Implications for reservoir limnology and management
}

\author{
Ana Maria Geraldes* ${ }^{1 *}$ and Maria-José Boavida ${ }^{2}$ \\ ${ }^{1}$ CIMO Escola Superior Agrária de Bragança, Campus de Santa Apolónia, Bragança, Portugal, and ${ }^{2}$ Centre of Environmental \\ Biology, Department of Animal Biology, Faculty of Science, University of Lisbon, Campo Grande, Lisbon, Portugal
}

\begin{abstract}
With the purpose of finding out whether seasonal water level fluctuations could affect water quality in a reservoir subjected to those changes, trends in environmental variables and in phytoplankton and zooplankton assemblages were analysed. The reservoir's hydrological cycle was characterized by three regimes. The maximum level phase lasted from January to the beginning of June, the emptying phase existed between mid-June to the beginning of September and the minimum level phase lasted from mid-September to the beginning of the first autumn/winter rain events. The highest values of total phosphorus, soluble reactive phosphorus, nitrate, water colour and chlorophyll $a$ were found during the minimum level phase. The phytoplankton assemblage was dominated by taxa typical of meso-eutrophic environments during the emptying and minimum level phases. However, during the maximum level phase, taxa generally found in more oligotrophic systems were observed here also. Similar to other disturbed systems, the zooplankton assemblage was dominated by Rotifera, except in summer and autumn when the cladoceran Ceriodaphnia quadrangula and/or the copepod Tropocyclops prasinus became dominant. Although those shifts seem to be related to water level variations, further research is needed to evaluate to what extent they might also be induced by other seasonal factors acting independently of water fluctuations. Based upon the obtained data, suggestions for reservoir management are proposed.
\end{abstract}

\section{Key words}

nutrients, phytoplankton and zooplankton assemblages, reservoir management, reservoirs, water level fluctuation.

\section{INTRODUCTION}

Physical, chemical and biological features in reservoirs are influenced by seasonal surface-level fluctuations, which are significantly associated with anthropogenic utilization (Wetzel 1990). Such fluctuations are more frequent in reservoirs located in regions where rain events are strongly seasonal and occur in an irregular precipitation regime. In these areas, local human populations intensively use the water stored in most of those reservoirs for urban water and hydroelectric power supply, irrigation and recreation. In spite of the current belief that water level fluctuations exert an influence on water quality, conditioning its use, there are few studies directed to understanding the mechanisms by which those hydrological patterns can influence reservoir dynamics. The discussions in the scientific literature focus largely on the effects of the filling

*Corresponding author. Email: geraldes@ipb.pt

Accepted for publication 24 February 2005. process in new reservoirs (Kimmel et al. 1988; Masundire 1992; Robarts et al. 1992; Garrido \& Bozelli 2000; Leitão \& Léglize 2000) or the effects of refilling reservoirs that were totally emptied for repairs (Pinel-Alloul \& Méthot 1984; Boavida \& Crispim 1993; Marques \& Boavida 1993; Crispim \& Boavida 1995; Geraldes \& Boavida 1999). Studies focusing on the effects of periodic reservoir water level fluctuations are even more scarce and were mostly performed on Sicilian (e.g. Barone \& Naselli-Flores 1994; Naselli-Flores 1999) and Australian (e.g. Watts 2000) reservoirs. Consequently, there is a paucity of basic information, which is required for effectively managing reservoirs subject to periodic water level fluctuations.

S. Serrada Reservoir is located in the Iberian Peninsula, in the Portuguese part of the River Douro catchment. Precipitation in this region occurs mainly in autumn and winter. However, it is a very irregular regime, with one wet winter usually followed by several dry ones. This reservoir is subjected to intense water use for urban supply during the summer months. Therefore, in a simplified way, the 
hydrological cycle of this reservoir is characterized by the following regime: (i) maximum level phase from January to the beginning of June; (ii) emptying phase from midJune to the beginning of September; and (iii) minimum level phase from mid-September to the beginning of the first autumn/winter rain events.

The objectives of this study were to examine how those water level fluctuations could affect: (i) total phosphorus (TP), soluble reactive phosphorus (SRP), nitrate $\left(\mathrm{N}-\mathrm{NO}_{3}\right)$ and chlorophyll $a$ concentrations (CHL $a$ ); (ii) water colour, water transparency, dissolved oxygen (DO) and conductivity; and (iii) phytoplankton and zooplankton assemblages. The ultimate goal was to offer valid suggestions for reservoir management based on these study results.

\section{Study site}

S. Serrada is located on granitic bedrock at an altitude of $1300 \mathrm{~m}$ a.s.l. The total capacity of the reservoir, occupying an area of $\approx 25 \mathrm{ha}$, is $1680 \times 10^{3} \mathrm{~m}^{3}$. The maximum depth is $17 \mathrm{~m}$ and the mean depth is $6.7 \mathrm{~m}$. The climate in the region in which the reservoir is located is continental in nature, with warm, dry summers and long, cold winters. As a result of the influence of the Mediterranean climate on the Iberian Peninsula, however, precipitation occurs mainly in autumn and winter, although in an irregular regime (Fig. 1). Direct human influence on the S. Serrada Reservoir is considered negligible. There are no villages, there has been no agricultural activity in the area for $\approx 20$ years and recreational activities are minimal. However, grazing can be very intense during the summer months in the drainage basin. Consequently, this area is very subject to wild fires, induced mainly by shepherds to obtain better grazing conditions.
The reservoir was filled for the first time in 1995 for urban supply and to generate hydroelectric power. Accentuated water level fluctuations occur because of these uses. The water level varies between $8 \mathrm{~m}$ and $10 \mathrm{~m}$ over the annual cycle (Fig. 2). Those variations are seasonal and related to precipitation events. Thermal stratification was observed from June - August/beginning of September (Fig. 3) during this study period. Disruption of thermal stratification was coincident with the lowest water level. During the study period, this reservoir was considered meso-eutrophic. Further information concerning morphological and hydrological characteristics of this reservoir are provided by Geraldes and Boavida (2003a).

\section{METHODS}

Water samples were collected monthly in winter and biweekly in summer from January 2000 - December 2002 at a single sampling station located at the deepest point of the reservoir. Water samples for SRP and TP determinations were obtained from the upper $30-40 \mathrm{~cm}$ stratum, put in acid-rinsed bottles and transported to the laboratory in a cold container. During the period of thermal stratification, water samples also were taken from the middle water column (7-10 $\mathrm{m}$ ) and from the bottom. The SRP concentration was estimated by the method of Murphy and Riley (1962) and the TP concentration was assessed after acid hydrolysis with persulphate for $60 \mathrm{~min}$ under high temperature and pressure (American Public Health Association 1989). Environmental variables, such as water temperature, DO, conductivity, $\mathrm{pH}$, as well as $\mathrm{N}-\mathrm{NO}_{3}$, ammonium ion and ammonia gas $\left(\mathrm{N}^{-} \mathrm{NH}_{3}\right)$ concentrations, were measured in situ at $1 \mathrm{~m}$ intervals with a multiparameter water quality monitor (Yellow Spring Instruments, Ohio, USA). Chlorophyll $a$

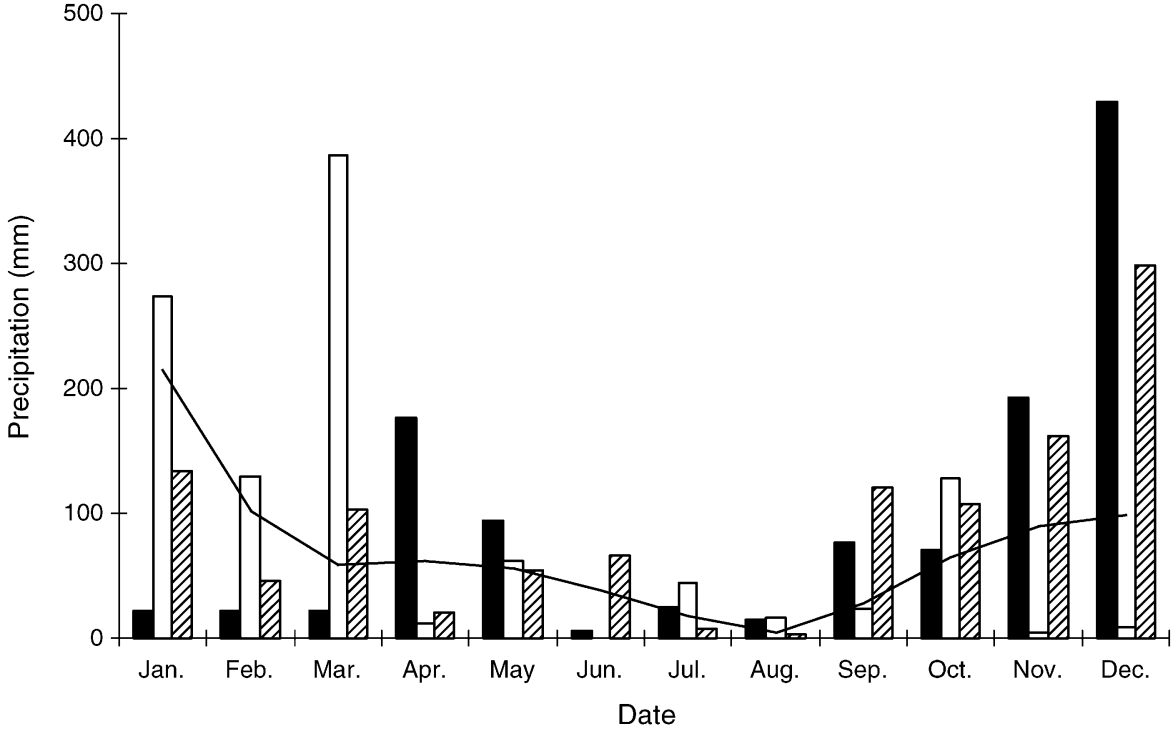

Fig. 1. Precipitation during the study period in Bragança, the main city closest to S. Serrada Reservoir (Agroclima Laboratory - ESAB, unpubl. data 2000-2002) and the mean values of the observed variables between 1960 and 1990 (Institute of Meteorology-Portugal 2001). $\mathbf{\square}, 2000 ; \square, 2001 ; \square$, 2002; - , mean value. 
samples were obtained from $500-1000 \mathrm{~mL}$ of an integrated water sample taken from the euphotic zone and filtered through a GF/A filter (Whatman International, Maidstone, England) within $2 \mathrm{~h}$ of its collection. The CHL $a$ concentrations were determined spectrophotometrically after overnight extraction in $90 \%$ acetone. Water colour was determined according to the method of Cuthbert and Giorgio (1992). The water transparency was measured with a $20 \mathrm{~cm}$-diameter, black-and-white Secchi disk.

Zooplankton samples were obtained on each sampling date by taking two vertical hauls using a Wisconsin-type net of $64-\mu \mathrm{m}$ mesh size. The organisms were anaesthetized with carbonated water and preserved in sugar-saturated formaldehyde ( $4 \%$ final concentration). Depending on the density, zooplankton were counted in 5,10 or $20 \mathrm{~mL}$ subsamples, or in a total sample. They were identified to the genus/species level. Integrated water samples were collected from the euphotic zone for phytoplankton analyses. Phytoplankton samples were fixed in situ in Lugol's solution and counted according to the method of Utermöhl (1958), using an inverted microscope (Nikon, Tokyo, Japan) at 200/400× magnification. Algae were identified to genus.

A Kruskal-Wallis test was performed for each environmental variable to determine whether mean values obtained at the maximum level phase, at the emptying phase and at the minimum level phase were significantly

Fig. 2. Water level variations in S. Serrada Reservoir during the

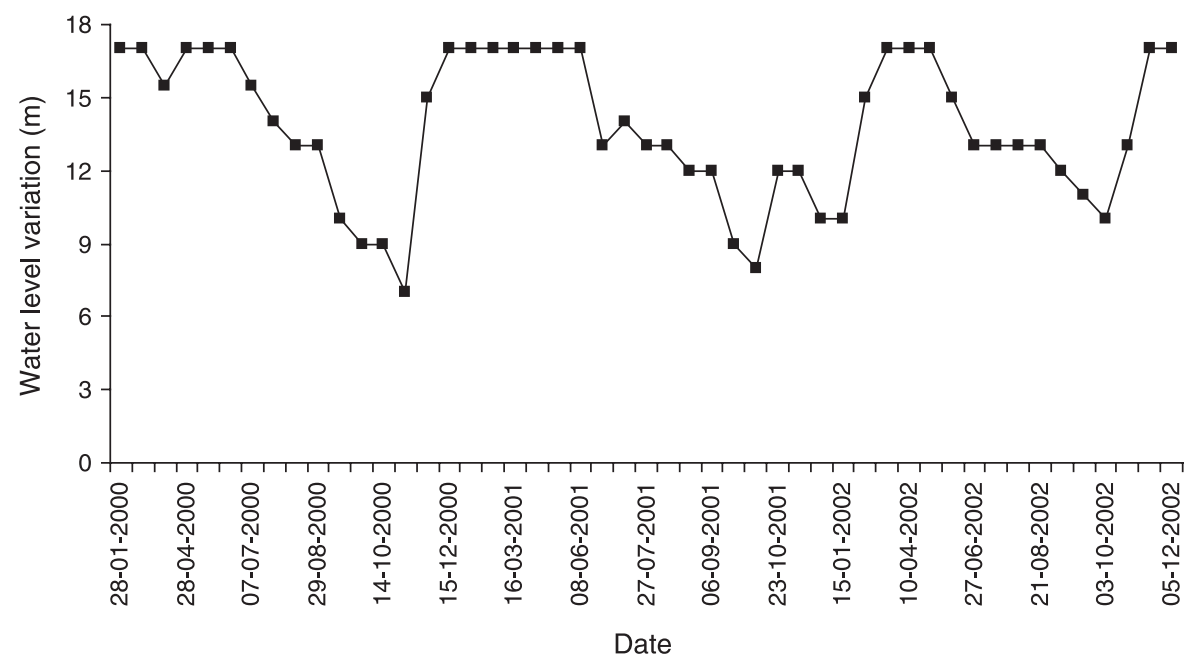
study period.

(a)

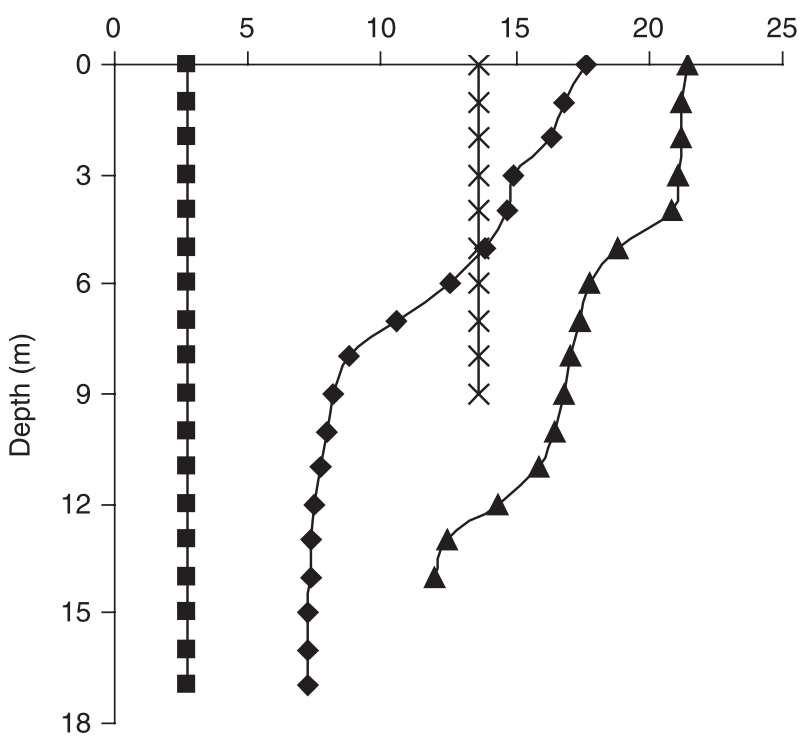

(b) Oxygen $\left(\mathrm{mg} \mathrm{L}^{-1}\right)$

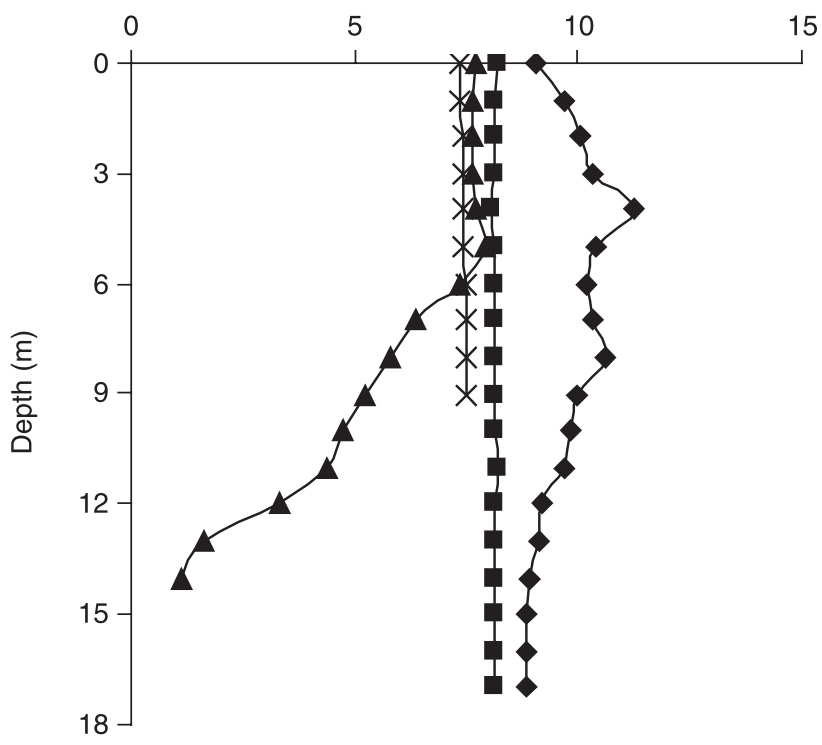

Fig. 3. (a) Seasonal temperature and (b) seasonal dissolved oxygen profiles in S. Serrada Reservoir. $\mathbf{\square}$, January; $\bullet$, early June; $\boldsymbol{\Delta}$, July; $\times$, August/September. 
different. This statistical analysis was performed using SYSTAT 8.0. (SPSS, Chicago, USA). To evaluate the association between taxa composition and environmental variables, a redundancy analysis (RDA) was performed. A linear model of ordination was used because a preliminary detrended correspondence analysis (DCA) resulted in turnovers of less than two standard deviations. According to Ter Braak (1995), this is the recommended criterion for choosing linear models of ordination, rather than unimodal models. The relative abundances of the most representative phytoplankton and zooplankton taxa were transformed to $\log (\mathrm{x}+1)$. For the purpose of statistical analyses, all pennate diatoms (except Tabellaria) were retained in a single category because all genera were present in low densities. The same procedure was adopted for Keratella species in the zooplankton community. Environmental variables showing skewed distributions were also $\log (\mathrm{x}+1)$ transformed. In RDA, a forward selection procedure was used to add significant explanatory variables to the model. Those were added in the order of the greatest additional contribution to the total variance explained. The statistical significance in RDA was assessed by Monte-Carlo permutation tests (9999 permutations). The computer programme CANOCO version 4.0 (Centre for Biometry, Wageningen, The Netherlands) was used to perform both the preliminary DCA and the RDA.

\section{RESULTS \\ Environmental variables}

The mean TP, $\mathrm{N}^{-\mathrm{NO}_{3}}$ and CHL $a$ concentrations, water colour and conductivity were highest during the minimum level phase. Conversely, the water transparency was lowest during the same period. The SRP mean concentrations also were slightly higher during this period than during the other months of the year, although those differences were not statistically significant. The TP, water colour, conductivity and CHL $a$ decreased during the maximum level phase. The mean $\mathrm{N}-\mathrm{NO}_{3}$ decreased during the emptying phase. The $\mathrm{N}^{-\mathrm{NH}_{3}}$ concentrations were always below detection limits (Table 1). During the study period, and depending on the precipitation intensity, S. Serrada Reservoir reached its maximum level phase in one or two weeks. Thus, at the beginning of the maximum level phase, the TP, N-NO, $\mathrm{CHL} a$ concentrations and water colour were high, and decreased thereafter.

\section{Phytoplankton and zooplankton assemblages}

Chlorophyceae, Bacillariophyceae, Cryptophyceae and Chrysophyceae were the most representative taxa in the phytoplankton community (Fig. 4(a)). Of the algae found in S. Serrada Reservoir (Table 2), only the most abundant
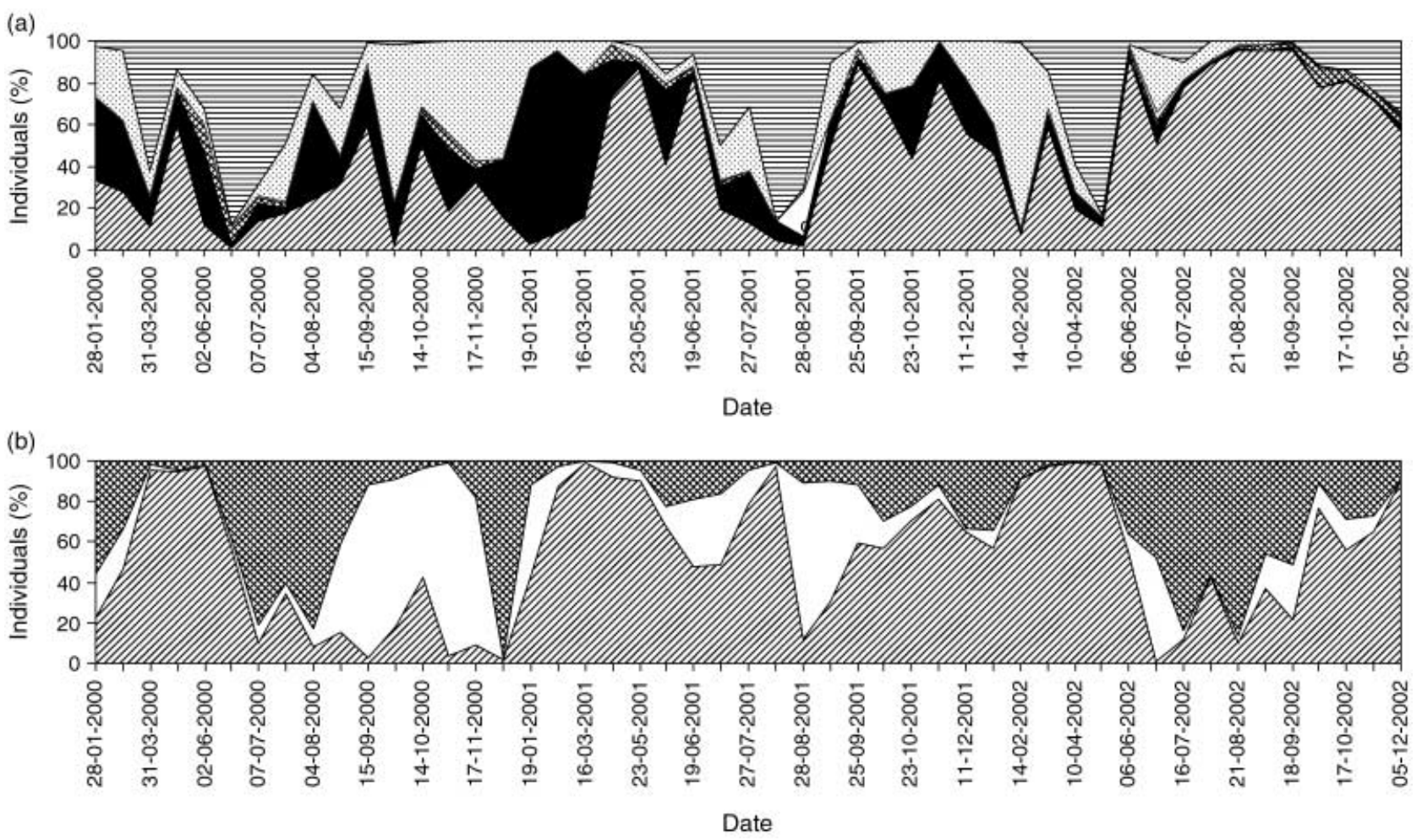

Fig. 4. (a) Relative abundance of the main phytoplankton taxa. $\mathrm{B}$, Chlorophyceae; $\mathbf{\square}$, Bacillariophyceae; 目, Cyanophyceae; $\square$, Dinophyceae; $\bigotimes$, Cryptophyceae; $\otimes$, Chrysophyceae. (b) Relative abundance of the main zooplankton taxa. $\square$, Rotifera; $\square$, Copepoda; $\otimes$, Cladocera. 
genera (Table 3) were considered in the RDA. The forward variable selection approach to RDA revealed a strong contribution of water temperature $(P=0.0001)$, water colour $(P=0.004)$ and $\mathrm{N}-\mathrm{NO}_{3}$ concentration $(P=0.007)$ to the observed significant association between phytoplankton assemblage and environmental variables (Monte-Carlo test; $P=0.0001$ ). The ordination space defined by the first two RDA axes (Fig. 5(a)) accounted for $80.5 \%$ of species-environment relations and represented $23.6 \%$ of the variation in species data. The distribution of sample scores in this ordination space reflected a clear distinction between the maximum level, the emptying and the minimum level phases.

Monoraphidium, Cyclotella and Tabellaria exhibited a tendency to increase when the water temperatures and colour were low, and intermediate $\mathrm{N}-\mathrm{NO}_{3}$ concentrations were recorded. Thus, their relative abundance was higher during the maximum water level phase. Conversely, Dinobryon seemed to prefer higher temperatures, low $\mathrm{N}-\mathrm{NO}_{3}$ concentrations

Table 1. Mean \pm standard deviation values of the environmental variables and minimum-maximum range for $\mathrm{pH}$ obtained during: (1) the maximum level phase, (2) the emptying phase and (3) the minimum level phase, as well as the results of the Kruskal-Wallis test. Abbreviations used in the redundancy analysis are indicated in brackets

\begin{tabular}{|c|c|c|c|c|}
\hline Variables & 1 & 2 & 3 & $P$ \\
\hline Water colour (Pt) (Col.) & $15.7 \pm 7.7$ & $18.0 \pm 12.6$ & $30.8 \pm 11.5$ & ** \\
\hline Water transparency $(\mathrm{m})$ (Secc.) & $2.9 \pm 0.9$ & $2.9 \pm 1.0$ & $1.7 \pm 0.4$ & ** \\
\hline \multicolumn{5}{|l|}{ Water temperature $\left({ }^{\circ} \mathrm{C}\right)$ (Temp.) } \\
\hline Surface & $9.3 \pm 5.5$ & $19.4 \pm 1.3$ & $10.2 \pm 4.1$ & ** \\
\hline Middle water column & $9.3 \pm 5.5$ & $16.3 \pm 2.1$ & $10.2 \pm 4.1$ & ** \\
\hline Bottom & $9.3 \pm 5.5$ & $11.1 \pm 2.3$ & $10.2 \pm 4.1$ & NS \\
\hline \multicolumn{5}{|l|}{ Dissolved oxygen $\left(\mathrm{mg} \mathrm{L}^{-1}\right)(\mathrm{DO})$} \\
\hline Surface & $8.6 \pm 1.6$ & $8.4 \pm 0.9$ & $8.6 \pm 1.5$ & NS \\
\hline Middle water column & $8.6 \pm 1.6$ & $6.9 \pm 2.0$ & $8.6 \pm 1.5$ & NS \\
\hline Bottom & $8.6 \pm 1.6$ & $3.2 \pm 2.9$ & $8.6 \pm 1.5$ & ** \\
\hline \multicolumn{5}{|l|}{ Conductivity $\left(\mu \mathrm{S} \mathrm{cm}^{-1}\right)$ (Cond.) } \\
\hline Surface & $6.0 \pm 1.5$ & $8.3 \pm 0.8$ & $8.1 \pm 1.5$ & ** \\
\hline Middle water column & $6.0 \pm 1.5$ & $8.5 \pm 3.7$ & $8.1 \pm 1.5$ & ** \\
\hline Bottom & $6.0 \pm 1.5$ & $14.6 \pm 10.2$ & $8.1 \pm 1.5$ & ** \\
\hline \multicolumn{5}{|l|}{$\mathrm{pH}(\mathrm{PH})$} \\
\hline Surface & $6.9-7.4$ & $5.4-8.1$ & $7.0-8.5$ & NS \\
\hline Middle water column & $6.9-7.4$ & $6.5-7.3$ & $7.0-8.5$ & NS \\
\hline Bottom & $6.9-7.4$ & $5.4-7.8$ & $7.0-8.5$ & NS \\
\hline \multicolumn{5}{|l|}{$\mathrm{N}-\mathrm{NO}_{3}\left(\mathrm{mg} \mathrm{L}^{-1}\right)\left(\mathrm{NO}_{3}\right)$} \\
\hline Surface & $5.8 \pm 8.7$ & $0.9 \pm 0.8$ & $13.3 \pm 15.2$ & $* *$ \\
\hline Middle water column & $5.8 \pm 8.7$ & $0.8 \pm 1.1$ & $13.3 \pm 15.2$ & ** \\
\hline Bottom & $5.8 \pm 8.7$ & $6.9 \pm 10.3$ & $13.3 \pm 15.2$ & * \\
\hline \multicolumn{5}{|l|}{$\mathrm{N}-\mathrm{NH}_{4}\left(\mathrm{mg} \mathrm{L}^{-1}\right)\left(\mathrm{NH}_{4}\right)$} \\
\hline Surface & $0.2 \pm 0.5$ & $0.1 \pm 0.2$ & $0.4 \pm 0.8$ & NS \\
\hline Middle water column & $0.2 \pm 0.5$ & $0.1 \pm 0.2$ & $0.4 \pm 0.8$ & NS \\
\hline Bottom & $0.2 \pm 0.5$ & $1.0 \pm 2.5$ & $0.4 \pm 0.8$ & NS \\
\hline \multicolumn{5}{|l|}{$\mathrm{TP}\left(\mu \mathrm{g} \mathrm{L}^{-1}\right)(\mathrm{TP})$} \\
\hline Surface & $59.9 \pm 25.3$ & $70.1 \pm 19.2$ & $82.0 \pm 11.4$ & ** \\
\hline Middle water column & $59.9 \pm 25.3$ & $92.2 \pm 25.7$ & $82.0 \pm 11.4$ & ** \\
\hline Bottom & $59.9 \pm 25.3$ & $136.5 \pm 35.1$ & $82.0 \pm 11.4$ & ** \\
\hline \multicolumn{5}{|l|}{$\operatorname{SRP}\left(\mu \mathrm{g} \mathrm{L}^{-1}\right)(\mathrm{SRP})$} \\
\hline Surface & $8.7 \pm 7.5$ & $6.6 \pm 4.7$ & $9.5 \pm 7.2$ & NS \\
\hline Middle water column & $8.7 \pm 7.5$ & $9.7 \pm 6.1$ & $9.5 \pm 7.2$ & NS \\
\hline Bottom & $8.7 \pm 7.5$ & $19.2 \pm 13.0$ & $9.5 \pm 7.2$ & ** \\
\hline \multicolumn{5}{|l|}{ Chlorophyll a $\left(\mu \mathrm{g} \mathrm{L}^{-1}\right)(\mathrm{CHL})$} \\
\hline Integrated sample & $1.7 \pm 1.3$ & $1.9 \pm 1.6$ & $8.0 \pm 4.7$ & $* *$ \\
\hline
\end{tabular}

$\mathrm{N}-\mathrm{NO}_{3}$, nitrate; $\mathrm{N}-\mathrm{NH}_{4}$, ammonium; TP, total phosphorus; SRP, soluble reactive phosphorus.

${ }^{*} P<0.05 ; * * P<0.01$; NS, not significant. 
Table 2. Composition of phytoplankton and zooplankton assemblages in S. Serrada Reservoir

\begin{tabular}{|c|c|}
\hline Phytoplankton & Zooplankton \\
\hline Chlorophyceae & Rotifera \\
\hline Botryococcus & Asplanchna priodonta \\
\hline Chlamydomonas & Collotheca sp. \\
\hline Closterium & Conochilus sp. \\
\hline Cosmarium & Euchelanis sp. \\
\hline Crucigenia & Gastropus sp. \\
\hline Dictyosphaerium & Hexarthra sp. \\
\hline Gonium & Keratella cochlearis \\
\hline Micrasterias & Keratella quadrata \\
\hline Monoraphidium & Keratella tecta \\
\hline Oocystis & Ploesoma sp. \\
\hline Paulschulzia & Polyarthra sp. \\
\hline Scenedesmus & Synchaeta sp. \\
\hline Selenastrum & Trichocerca sp. \\
\hline Staurastrum & Cladocera \\
\hline Staurodesmus & Alona costata \\
\hline Tetraedron & Alona quadrangularis \\
\hline Bacillariophyceae & Alona rectangula \\
\hline Amphora & Alona sp. \\
\hline Aulacoseira & Bosmina longirostris \\
\hline Cocconeis & Ceriodaphnia quadrangula \\
\hline Craticula & Chydorus sphaericus \\
\hline Cyclotella & Daphnia longispina \\
\hline Cymbella & Simocephalus sp. \\
\hline Gomphonema & Copepoda \\
\hline Gyrosigma & Eucyclops serrulatus \\
\hline Navicula & Macrocyclops albidus \\
\hline Nitzschia & Tropocyclops prasinus \\
\hline Tabellaria & Nauplii \\
\hline \multicolumn{2}{|l|}{ Cyanophyceae } \\
\hline \multicolumn{2}{|l|}{ Anabaena } \\
\hline \multicolumn{2}{|l|}{ Chroococcus } \\
\hline \multicolumn{2}{|l|}{ Merismopedia } \\
\hline \multicolumn{2}{|l|}{ Dinophyceae } \\
\hline \multicolumn{2}{|l|}{ Gymnodinium } \\
\hline \multicolumn{2}{|l|}{ Peridinium } \\
\hline \multicolumn{2}{|l|}{ Euglenophyceae } \\
\hline \multicolumn{2}{|l|}{ Trachelomonas } \\
\hline \multicolumn{2}{|l|}{ Cryptophyceae } \\
\hline \multicolumn{2}{|l|}{ Cryptomonas } \\
\hline \multicolumn{2}{|l|}{ Chrysophyceae } \\
\hline \multicolumn{2}{|l|}{ Dinobryon } \\
\hline \multicolumn{2}{|l|}{ Mallomonas } \\
\hline Synura & \\
\hline
\end{tabular}

and low water colour. Therefore, the relative abundance of this genus was higher during the emptying phase. Aulacoseira, Peridinum, Cosmarium and Anabaena were associated with low $\mathrm{N}-\mathrm{NO}_{3}$ concentrations and high temperatures. Whereas, Staurastrum, Staurodesmus, Scenedesmus, Tetraedron and Crucigenia were associated with high N$\mathrm{NO}_{3}$ concentrations, high water colour and intermediate temperatures. Thus, those taxa were more abundant during the minimum level phase. Cryptomonas occupied a central position in the ordination space, which might denote an ecological flexibility of this taxon to grow under a wide range of environmental conditions.

Rotifera included the most abundant taxa, except in summer and in autumn when Cladocera and Copepoda became dominant (Fig. 4(b)). Of the zooplankton species found in S. Serrada Reservoir (Table 2), only the most representative were considered in the RDA (Table 4). The forward variable selection approach to the RDA revealed a strong contribution of temperature $(P=0.005)$, CHL $a(P=0.007)$, SRP $(P=0.01)$ and TP $(P=0.03)$ concentrations to the observed significant associations between the zooplankton assemblage and environmental variables (Monte-Carlo test; $P=0.005$ ). The ordination space defined by the first two RDA axes (Fig. 5(b)) accounted for $84.2 \%$ of species-environment relations and represented $25.4 \%$ of the variation in species data. The distribution of sample scores in this ordination space reflected a clear distinction between the maximum level phase and the emptying/minimum level phases. However, the distinction between the latter two phases was not so clear. Daphnia were associated with lower temperatures and the maximum level phase. Conversely, Ceriodaphnia was clearly related to the emptying phase, when the temperature was higher. Conochilus and Asplanchna were associated with low values of TP and CHL $a$ (maximum level phase). Polyarthra abundance also was high during this period. In the ordination space, however, this latter species was associated with high TP concentrations. In fact, the abundance of this rotifer was higher after strong rain events when the TP concentrations concomitantly increased. Gastropus, Keratella, Hexarthra, Tropocyclops prasinus and nauplii abundances were related to the increase in system instability and to the higher TP and CHL $a$ concentrations during the emptying and the minimum level phases.

\section{DISCUSSION Environmental variables}

The increase of TP, $\mathrm{N}-\mathrm{NO}_{3}$ and $\mathrm{CHL} a$ concentrations during the emptying and minimum level phases could have been a consequence of the increment of suspended particulate material (SPM) in the water column resulting 
from water turbulence generated during the emptying phase, plus the disruption of thermal stratification at the end of this phase. Barone and Naselli-Flores (1994) and Naselli-Flores (1999) observed a similar increase in phytoplankton biomass, supported by the renewed availability of nutrients at the end of the emptying phase in Sicilian reservoirs subjected to severe water level fluctuations.

An increase in water colour also was observed in S. Serrada Reservoir. This parameter is a measure of the concentration of humic compounds resulting from terrestrial plant decomposition (Cuthbert \& Giorgio 1992). Thus, high water colour might indicate the presence of large amounts of decomposition products of terrestrial vegetation in the water column. Moreover, the disturbances caused by sheep grazing activity and frequent fires in the drainage basin appeared to be another source of organic matter (Geraldes \& Boavida 2003a). The nutrient concentrations and water colour decreased during the maximum level phase, which was a period of water level stability. Consequently, the sedimentation of particulate material could have been favoured (Boström et al. 1988; Wetzel 2001).
Another consequence of the disturbance caused by extreme water level fluctuations is the exposure of littoral sediments to cycles of drying and wetting, which might have implications on nutrient cycling (mainly phosphorus $(\mathrm{P})$ availability). This assumption is supported by results obtained by Fabre (1988) and Watts (2000) in reservoirs where water level fluctuations were accentuated and where refilling occurred over a short time period. According to those authors, littoral sediments periodically exposed during cycles of drying and wetting have less capacity to adsorb nutrients than those that remain inundated. Preliminary experiments based on the experimental design developed by Watts (2000) showed that the sediments that were periodically exposed in S. Serrada Reservoir released greater amounts of SRP after the addition of water than those that were permanently inundated (Geraldes, unpubl. data 2002).

\section{Phytoplankton and zooplankton assemblages}

During the maximum level phase, the phytoplankton assemblage was composed of taxa strongly associated with low temperatures and was generally found in: (i) nutrient-

Table 3. The most common genera of the phytoplankton assemblage based on using the mean \pm standard deviation of the relative abundances during: (1) the maximum level phase, (2) the emptying phase and (3) the minimum level phase. Taxa abbreviations used in the redundancy analysis are indicated in brackets

\begin{tabular}{|c|c|c|c|}
\hline Phytoplankton & 1 & 2 & 3 \\
\hline \multicolumn{4}{|l|}{ Chlorophyceae } \\
\hline Cosmarium (Cosm.) & $5.02 \pm 13.50$ & $6.57 \pm 18.09$ & $1.04 \pm 1.11$ \\
\hline Crucigenia (Cruc.) & $1.67 \pm 2.04$ & $1.61 \pm 2.64$ & $2.64 \pm 4.53$ \\
\hline Dictiospaerium (Dict.) & $4.96 \pm 8.97$ & $2.78 \pm 3.46$ & $6.59 \pm 8.60$ \\
\hline Monoraphidium (Mono.) & $13.39 \pm 20.76$ & $1.93 \pm 3.88$ & $5.96 \pm 7.54$ \\
\hline Oocystis (Oocy.) & $0.28 \pm 0.57$ & $0.22 \pm 0.65$ & $0.04 \pm 0.11$ \\
\hline Scenedesmus (Scen.) & $0.62 \pm 1.89$ & $1.90 \pm 4.04$ & $2.63 \pm 2.24$ \\
\hline Staurastrum (Stau.) & $5.21 \pm 13.27$ & $26.05 \pm 38.86$ & $35.29 \pm 28.80$ \\
\hline Staurodesmus (Star.) & $0.33 \pm 0.71$ & $0.49 \pm 0.79$ & $3.16 \pm 6.35$ \\
\hline Tetraedron (Tetr.) & $0.04 \pm 0.12$ & $0.79 \pm 1.79$ & $1.30 \pm 2.28$ \\
\hline \multicolumn{4}{|l|}{ Bacillariophyceae } \\
\hline Aulacoseira (Aulo.) & $0.22 \pm 0.38$ & $0.45 \pm 0.57$ & $0.09 \pm 0.23$ \\
\hline Cyclotella (Cycl.) & $12.90 \pm 16.71$ & $6.74 \pm 13.10$ & $9.61 \pm 11.07$ \\
\hline Pennate diatoms (Pen.) & $2.74 \pm 7.79$ & $3.33 \pm 8.26$ & $3.79 \pm 5.83$ \\
\hline Tabellaria (Tabe.) & $8.81 \pm 14.83$ & $2.97 \pm 2.83$ & $2.54 \pm 2.31$ \\
\hline \multicolumn{4}{|l|}{ Cyanophyceae } \\
\hline Anabaena (Anab.) & $2.47 \pm 3.31$ & $1.11 \pm 0.97$ & $2.72 \pm 3.03$ \\
\hline \multicolumn{4}{|l|}{ Dinophyceae } \\
\hline Peridinium (Peri.) & $0.31 \pm 0.59$ & $2.08 \pm 5.30$ & $0.04 \pm 0.13$ \\
\hline \multicolumn{4}{|l|}{ Cryptophyceae } \\
\hline Cryptomonas (Cryp.) & $20.12 \pm 23.84$ & $14.67 \pm 12.30$ & $22.20 \pm 18.39$ \\
\hline \multicolumn{4}{|l|}{ Chrysophyceae } \\
\hline Dinobryon (Dino.) & $20.90 \pm 30.20$ & $26.26 \pm 28.98$ & $0.36 \pm 0.61$ \\
\hline
\end{tabular}


poor environments (Tabellaria, Cosmarium and Dinobryon; Reynolds 1998); (ii) mesotrophic environments (Cyclotella; Lecointe et al. 1993); and (iii) enriched environments and/ or transient phases of filling (Monoraphidium; Reynolds 1999). However, phytoplankton assemblage structure also could have been influenced by the complex interactions of physical, chemical and biological factors. Therefore, it is plausible to assume that Daphnia (which, coincidentally, reached its maximum abundance during this period) could have exerted some grazing control over edible algae, thereby influencing the composition of the phytoplankton assemblage (Lampert \& Sommer 1997). (a)

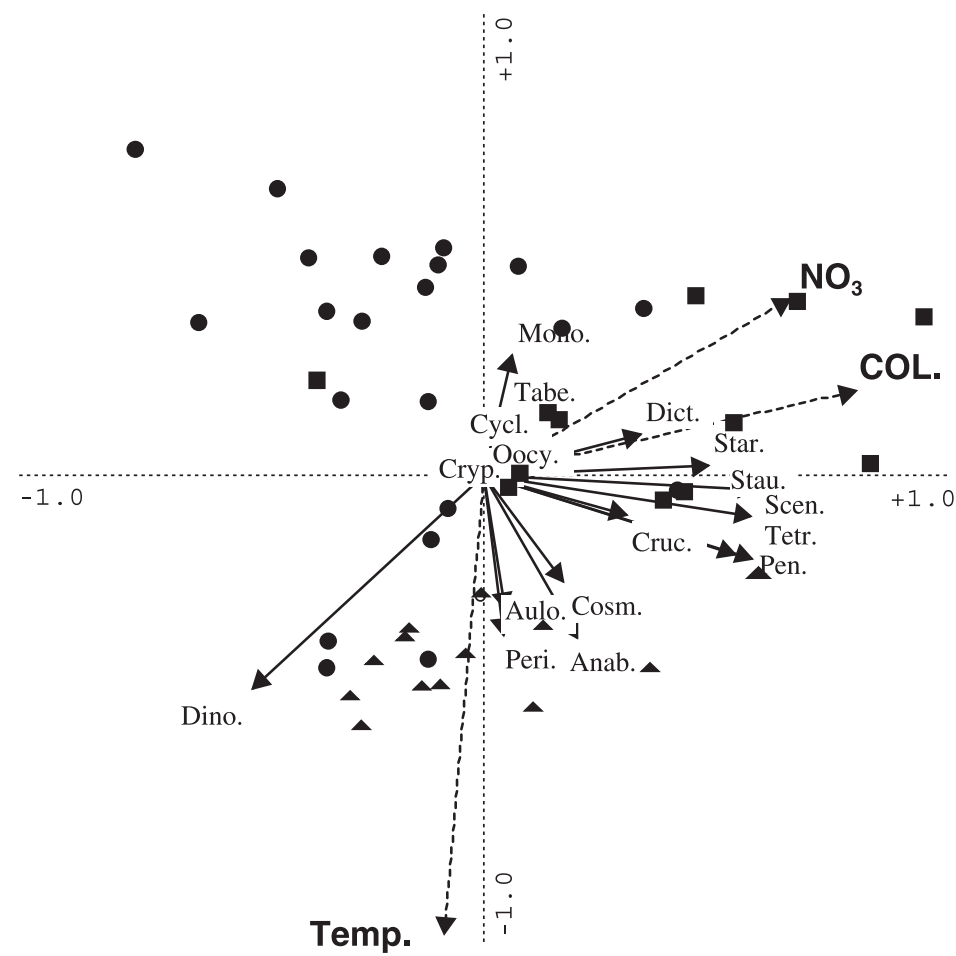

(b)

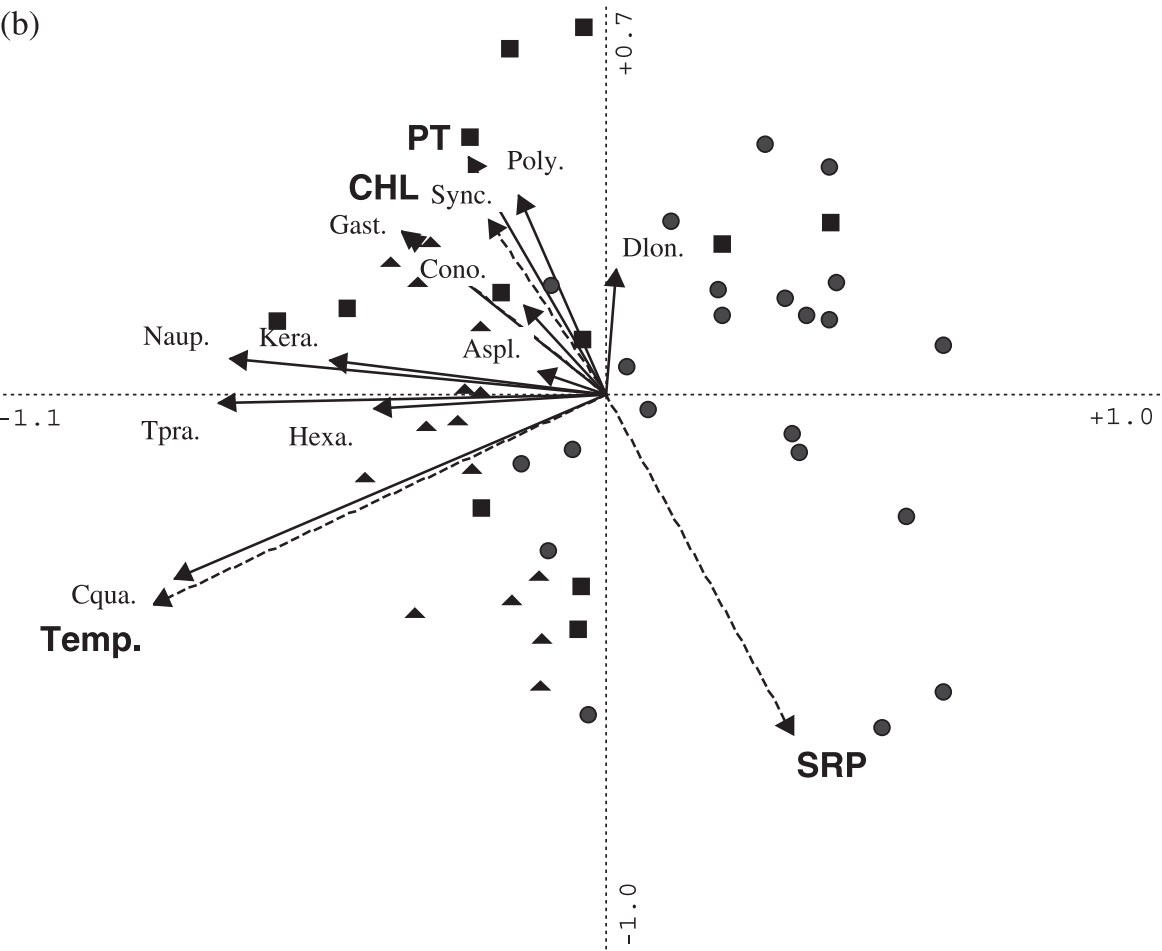

Fig. 5. Redundancy analysis ordination diagram depicting the effects of environmental variables on: (a) phytoplankton and (b) zooplankton assemblages. $\bullet$ samples taken during the maximum level phase; $\boldsymbol{\Delta}$, samples taken during the emptying phase; - samples taken during the minimum level phase. Dashed arrows are species and solid arrows are environmental variables indicating significant correlations with the canonical axes. Col., water colour; $\mathrm{CHL}$, chlorophyll $\mathrm{a} ; \mathrm{NO}_{3}$, nitrate; $\mathrm{PT}$, total phosphorus; SRP, soluble reactive phosphorus; Temp., temperature; Anab., Anabaena; Aulo., Aulacoseira; Cosm., Cosmarium; Cruc., Crucigenia; Cry., Cryptomonas; Cycl., Cyclotella; Dict., Dictiospaerium; Dino., Dinobryon; Mono., Monoraphidium; Oocy., Oocystis; Pen., pennate diatoms; Peri., Peridinium; Scen., Scenedesmus; Star., Staurodesmus; Stau., Staurastrum; Tabe., Tabellaria; Tetr., Tetraedron; Aspl., Asplanchna; Cono., Conochilus; Cqua., Ceriodaphnia; Dlon., Daphnia; Gast., Gastropus; Hexa., Hexarthra; Kera., Keratella; Naup., nauplii; Poly., Polyarthra; Sync., Synchaeta; Tpra., Tropocyclops. 
During both the emptying and minimum level phases, an increase in Scenedesmus, Crucigenia and Peridinum, together with the dominance of Staurastrum, was observed. Those species are typically found in mesoeutrophic environments (Reynolds 1998). Some Staurastrum species also are common in reservoirs with large quantities of organic matter (Negro et al. 2000). However, the increase in TP and SRP concentrations did not appear to have a significant influence on the phytoplankton assemblage composition or structure. In fact, the concentrations of those $\mathrm{P}$ forms were always high and preliminary experiments on $\mathrm{P}$ limitation indicated that $\mathrm{P}$ was not the algal biomass limiting nutrient (Geraldes \& Boavida 2003b). Changes in water temperature and the increase in $\mathrm{N}^{-\mathrm{NO}_{3}}$ concentrations in the water column were probably the factors responsible for these shifts. Similar to other reservoirs (Barone et al. 1991; NaselliFlores \& Barone 1994; Naselli-Flores 1999), the reduction of light penetration into the water column caused by the increase in SPM, together with changes in the zooplankton, could have influenced the algal community composition.

Zooplankton exhibiting small particle feeding, whose food preferences are mostly comprised of detritusbacteria and small phytoplankton, always dominated the zooplankton assemblage in this reservoir. Most zooplanktons (including Ceriodaphnia and T. prasinus) can only ingest particles $<20 \mu \mathrm{m}$ (Lampert \& Sommer 1997). Those assemblage patterns are typical of reservoirs subjected to periodic water level variations (Schmid-Araya
\& Zuñiga 1992). According to those authors, the abovementioned species exhibit adaptive advantages over larger Cladocera and Copepoda, not only because of their feeding behaviour, but also because they are r-strategists, having shorter generation times and a greater tolerance to large amounts of organic matter in the water. An exception was Conochilus which, according to Sladeček (1983), is typical of environments poor in organic matter. However, seasonal succession could have been related not only to changes in environmental variables caused (or not) by water level fluctuations, but also to biotic interactions. Examples could be the competitive interactions that might have occurred among Ceriodaphnia and some rotifers, as well as shifts in phytoplankton assemblages (Lampert \& Sommer 1997). As a wide range of physical and chemical interactions is likely to influence the phytoplankton and zooplankton assemblages, it is necessary to be cautious when relating the observed changes to water level variations. In fact, some shifts in those assemblages could have been induced directly or indirectly by water fluctuations, while others could have been caused by factors that vary seasonally, but independently, of water level fluctuations (e.g. water temperature).

\section{Management implications and concluding remarks}

One could expect S. Serrada Reservoir to be oligotrophic or mesotrophic because reservoirs and lakes located in similar climatic and geological regions of the Iberian Peninsula are generally found to exhibit these trophic

Table 4. The most common taxa of the zooplankton assemblage based on using the mean \pm standard deviation of the relative abundances during: (1) the maximum level phase, (2) the emptying phase and (3) the minimum level phase. Taxa abbreviations used in the redundancy analysis are indicated in brackets

\begin{tabular}{lccc}
\hline Zooplankton & 1 & 2 & 3 \\
\hline Rotifera & & & \\
$\quad$ Asplanchna (Aspl.) & $20.89 \pm 29.48$ & $4.37 \pm 8.92$ & $6.03 \pm 12.33$ \\
Conochilus (Cono.) & $26.46 \pm 33.55$ & $2.59 \pm 7.46$ & $3.67 \pm 6.40$ \\
Gastropus (Gast.) & $0.21 \pm 0.83$ & $0.47 \pm 1.72$ & $0.35 \pm 0.63$ \\
Hexarthra (Hexa.) & $0.05 \pm 0.15$ & $1.08 \pm 1.72$ & $0.19 \pm 0.60$ \\
Keratella (Kera.) & $7.38 \pm 14.04$ & $16.82 \pm 28.21$ & $16.06 \pm 24.05$ \\
Polyarthra (Poly.) & $12.15 \pm 25.64$ & $1.15 \pm 2.08$ & $6.42 \pm 10.30$ \\
Synchaeta (Sync.) & $2.20 \pm 4.70$ & $2.63 \pm 3.84$ & $17.83 \pm 19.74$ \\
Cladocera & & & $7.71 \pm 8.19$ \\
Ceriodaphnia (Cqua.) & $22.17 \pm 24.89$ & $1.90 \pm 2.31$ \\
Daphnia (Dlon.) & $6.97 \pm 18.41$ & $0.42 \pm 0.76$ & $26.76 \pm 30.55$ \\
Copepoda & $4.94 \pm 13.37$ & & $13.00 \pm 13.42$ \\
Tropocyclops (Tpra.) & & $17.43 \pm 22.30$ & $30.87 \pm 28.53$ \\
$\quad$ Nauplii (Naup) & $11.93 \pm 19.76$ & & \\
\hline
\end{tabular}


conditions (Boavida 2000; Negro et al. 2000). However, S. Serrada Reservoir also is a highly disturbed system, if compared to most other reservoirs in the region. The intense water use accentuates water level fluctuations in the reservoir, contributing to a large increase in nutrient and organic matter concentrations in the water column. This increases the costs of water treatment by municipalities because of the degradation of water quality and ecosystem health related to the increased suspended particulate concentrations in the water column. Relevant information for resident populations is urgently needed to prevent water waste. This measure would allow the maintenance of higher water levels during the summer months, thereby resulting in a smaller area of littoral sediments being exposed to cycles of drying and wetting. The quantity of SPM in the water column would be reduced as well, thereby reducing the internal loading of nutrients and organic matter to the water body.

Measures that should be implemented to protect the reservoir include: (i) reducing the external sources of nutrients and organic matter; (ii) preventing frequent fires in the catchment area; (iii) forbidding sheep grazing on the reservoir shores; and (iv) promoting vegetation growth on the reservoir shoreline. Furthermore, because there is a paucity of long-term data regarding environmental variations and their influences on biotic community dynamics, additional research work also should be performed to fill this data gap, complementary to the suggested measures. It also is important to understand the extent that shifts in reservoir dynamics (mainly the biotic components) are induced by water fluctuations and/or seasonal factors that act independently of water level fluctuations. Such data are fundamental to developing predictive water quality models adapted to this particular region, particularly those needed to facilitate the development and implementation of appropriate management practices, with a multi-use perspective for the reservoir and its drainage basin.

\section{ACKNOWLEDGEMENTS}

This study was supported by Fundação para a Ciência e a Tecnologia, Portugal and a doctoral fellowship awarded to Ana Maria Geraldes for the last part of the study. The assistance of A. Ribeiro, A. Teixeira, N. Marcos, D. Saraiva and S. Branco in the field work also was greatly appreciated.

\section{REFERENCES}

American Public Health Association (1989) Standard Methods for the Examination of Water and Wastewater. American Public Health Association, Washington DC.
Barone R. \& Naselli-Flores L. (1994) Phytoplankton dynamics in a shallow, hypertrophic reservoir (Lake Arancio, Sicily). Hydrobiologia 289, 199-214.

Barone R., Naselli- Flores L. \& Calvo S. (1991) Plankton communities in the artificial lakes of Sicily (Italy). Verh. Int. Verein. Limnol. 24, 1409-14.

Boavida M. J. (2000) Os lagos da Serra da Estrela (Portugal). In: Conservación de Los Lagos y Humedales de Alta Montaña de la Península Ibérica. (eds I. G. Martínez \& M. T. Velasco) pp. 79-86. Universidad Autónoma de Madrid, Madrid, Spain.

Boavida M. J. \& Crispim M. C. (1993) Study of zooplankton populations as a 35-year reservoir is being emptied. Verh. Int. Verein. Limnol. 25, 1204-6.

Boström B., Persson G. \& Broberg B. (1988) Bioavailability of different phosphorus forms in freshwater systems. Hydrobiologia 170, 21-34.

Crispim M. C. \& Boavida M. J. (1995) Comparison of rotifer communities in Maranhão Reservoir (Portugal) before its complete emptying and on refilling. Hydrobiologia 313/314, 325-32.

Cuthbert I. D. \& Giorgio P. (1992) Towards a standard method of measuring color in freshwater. Limnol. Oceanogr. 37, 1319-26.

Fabre A. (1988) Experimental studies on some factors influencing phosphorus solubilization in connexion with the drawdown of a reservoir. Hydrobiologia 159, 153-8.

Garrido A. V. \& Bozelli R. L. (2000) The study of zooplankton during the filling of the Serra da Mesa Reservoir, Tocatins River (Go, Brazil). Verh. Int. Verein. Limnol. 27, 2875-8.

Geraldes A. M. \& Boavida M. J. (1999) Comparison of a brand new reservoir with a near 40 year old reservoir which has been totally emptied and refilled. Lakes Reserv.: Res. Manage. 4, 15-22.

Geraldes A. M. \& Boavida M. J. (2003a) Distinct age and landscape influence on two reservoirs under the same climate. Hydrobiologia 504, 277-88.

Geraldes A. M. \& Boavida M. J. (2003b) Do distinct water chemistry, reservoir age and disturbance make any difference on phosphatase activity? J. Limnol. 62, 16371.

Institute of Meteorology-Portugal (2001) Informação Climática. Available from URL: http://www.meteo.pt. Accessed 5 January 2003.

Kimmel B. L., Soballe D. M., Adams S. M., Palumbo A. V., Ford C. J. \& Bevelhimmer M. S. (1988) Inter-reservoir interactions: Effects of a new reservoir on organic matter production and processing in a multipleimpoundment series. Verh. Int. Verein. Limnol. 23, 98594. 
Lampert W. \& Sommer U. (1997) Limnoecology - the Ecology of Lakes and Streams. Oxford University Press, New York.

Lecointe C., Coste M. \& Prygiel J. (1993) 'OMNIDIA' software for taxonomy, calculation of diatom indices and inventories management. Hydrobiologia 269/270, 50913.

Leitão M. \& Léglize L. (2000) Long-term variations of epilimnetic phytoplankton in an artificial reservoir during 10-year survey. Hydrobiologia 424, 39-49.

Marques R. T. \& Boavida M. J. (1993) Effects of water level fluctuation on the forms of phosphorus in mesotrophic Maranhão reservoir. Verh. Int. Verein. Limnol. 25, 1207-9.

Masundire H. M. (1992) The filling phase of Mazvikadei Reservoir, Zimbabwe. Hydrobiologia 232, 11-7.

Murphy J. \& Riley J. P. (1962) A modified single solution method for the determination of phosphate in natural waters. Anal. Chim. Acta. 27, 31-6.

Naselli-Flores L. (1999) Limnological aspects of Sicilian reservoirs: A comparative ecosystemic approach. In: Theoretical Reservoir Ecology (eds J. G. Tundisi \& M. Straškraba) pp. 283-311. International Institute of Ecology, Brazilian Academy of Sciences, São Carlos, Brazil.

Naselli-Flores L. \& Barone R. (1994) Relationship between trophic state and plankton community structure in 21 Sicilian dam reservoirs. Hydrobiologia 275/276, 197205.

Negro A. I., De Hoyos C. \& Vega J. C. (2000) Phytoplankton structure and dynamics in Lake Sanabria and Valparaíso reservoir (NW Spain). Hydrobiologia 424, 25-37.

Pinel-Alloul B. \& Méthot G. (1984) Analyse multidimensionnelle de l'evolution du zooplancton durant la mise en eau de trois reservoirs du nord du
Québec, Canada. Verh. Int. Verein. Limnol. 22, 144455.

Reynolds C. S. (1998) What factors influence the species composition of phytoplankton in lakes of different trophic status? Hydrobiologia 369/370, 11-26.

Reynolds C. S. (1999) A comparative ecosystemic approach. In: Theoretical Reservoir Ecology (eds J. G. Tundisi \& M. Straškraba) pp. 439-56. International Institute of Ecology, Brazilian Academy of Sciences, São Carlos, Brazil.

Robarts R. D., Zohary T., Jarvis A. C., Pais-Madeira C. M., Sephton L. M. \& Combrink S. (1992) Phytoplankton and zooplankton population dynamics and production of a recently formed African reservoir. Hydrobiologia 237, 47-60.

Schmid-Araya J. M. \& Zuñiga L. R. (1992) Zooplankton community structure in two Chilean reservoirs. Arch. Hydrobiol. 123, 305-35.

Sladeček V. (1983) Rotifers as indicators of water quality. Hydrobiologia 100, 169-201.

Ter Braak C. J. F. (1995) Ordination. In: Data Analysis in Community and Landscape Ecology (eds R. H. G. Jongman, C. J. F. Ter Braak \& O. F. R. van Tongeren) pp. 91-173. Cambridge University Press, New York.

Utermöhl H. (1958) Zur vervolkommnung der quantitativen phytoplankton methodik. Mitt. Int. Verein. Limnol. 9, 1-38.

Watts C. J. (2000) Seasonal phosphorus release from exposed, re-inundated littoral sediments of two Australian reservoirs. Hydrobiologia 431, 27-39.

Wetzel R. G. (1990) Reservoir ecosystems: Conclusions and speculations. In: Reservoir Limonology: Ecological Perspectives (eds K. W. Thornton, B. L. Kimmel \& F. E. Payne) pp. 227-38. Wiley, New York.

Wetzel R. G. (2001) Limnology - Lake and River Ecosystems, 3rd edn. Academic Press, San Diego. 